\title{
Complementing existing CHP plants with pyrolysis and gasification to produce liquid biofuels
}

\author{
Elena Tomás-Aparicio ${ }^{1}$, Chaudhary Awais Salman ${ }^{2}$, Erik Dahlquist ${ }^{2}$, Selman Ahmeddin $^{2}$, Hussein \\ Abdirizak Mohamed ${ }^{2}$ \\ ${ }^{1}$ Mälarenergi AB, Sweden elena.tomas-aparicio@malarenergi.se \\ ${ }^{2}$ School of Business Society and Engineering, Division of Automation in Energy and Environmental Engineering, \\ Mälardalen University, Sweden, \{chaudhary.awais.salman, erik.dahlquist, san15006@student, \\ hmd16001@student\}@mdh.se
}

\begin{abstract}
In Northern Europe there are many CHP plants operating with biomass and waste as fuel. As more wind and solar power is introduced the operating hours of these plants is reduced and thereby also the capital burden is distributed on fewer annual hours. At the same time there is a strong request to replace fossil oil by renewable alternatives for many different purposes. Here biomass and waste are the major resources available to produce liquid or gaseous bio-based products at existing CHP plants. In this study we have simulated system solutions to identify energy and material balances as well as rough economic figures. The products assumed are primarily fuels like diesel, hydrogen and methane, but also other organic compounds can be considered. Today PREEM and St1 are planning large scale production of primarily biodiesel, or HVO, where liquid products from both pulp and paper industry and CHP plants will be suitable feedstock. The study includes a comparison between hydrogen production in gasifiers to electrolysis, and even a combination of these as oxygen from the electrolyser can be used for the gasification, to avoid ballast of nitrogen in the product gas. The study aims to identify optimal solution under different conditions with respect to both electricity and raw material costs, as well as capital cost and operating hours.
\end{abstract}

Keywords: CHP, pyrolysis, gasification, HVO, liquid bio-fuel, hydrogen.

\section{Introduction}

Pyrolysis has been studied as a method to convert solid biomass into liquid bio-oil. A certain percentage of the biomass is converted to bio-oil and gaseous compounds, while a residue of mainly carbon is also produced. At Brista (Stockholm Exergi) an interest has been to produce bio-char primarily (Jonsson, 2016) while the bio-oil is the primary product in e.g. Joensuu pyrolyser plant (Joensuu, 2013). This is considered one of the first large scale pyrolisers for converting biomass to bio-oil. The production is around 50000 ton per year. At Setra in Gävle, Sweden, saw dust will be converted to bio-oil as well, with a capacity of approximately 30000 ton per year (Setra, 2019). The goal is to have the plant up and running at the end of 2021. Here PREEM is one of the part owners. PREEM has a plan to produce 3 million $\mathrm{m}^{3}$ bio-diesel and other bio-fuels per year by 2030 being this is a driving force for pyrolysis of biomass in Sweden. Already today PREEM is producing all their diesel with 30\% HVO (hydrogenated vegetable oils) including one third tall oil and two thirds vegetable oil, mostly palm oil. At Chalmers University tests have been performed with pyrolysis (2 MW) in the G-valve of an 8 MW CFB (Circulating Fluidized Bed) boiler. Approximately $70 \%$ of the biomass has been converted to gases, while the remaining solid fraction is passing down into the CFB bed, where the solids are combusted (Larsson et al, 2013). Most of the gases are condensed into liquids, which is an energy rich mixture of hydrocarbons. At Gobi gas a demonstration plant is operated to convert solid biomass into hydrocarbons using the FT (Fischer-Tropsch) process (Larsson et al, 2018). The product then can be used to replace fossil hydrocarbons. In Gussingen a steam-based gasification has been demonstrated in a CHP plant to produce a nitrogen free gas with high heating value $\left(12 \mathrm{MJ} / \mathrm{Nm}^{3}\right)$. This was reported in Rauch et al (2004). An alternative route can also be to utilize black liquors from pulp and paper industry, and especially the tall oil. Tall oil has been refined at Sunpine in Piteå followed by hydrogenation and distilled at PREEM oil refinery in Gothenburg. Here the oil is reacted with hydrogen to get a product equal to the fossil oil used to produce diesel and kerosene. From the previous work it can be concluded that CHP plants can be used also for production of liquid bio-fuels. In this system study we are looking for the possibility to convert solid biomass to bio-oil by integration to existing CFB-boilers at Malarenergi AB's CHP, but principally any FB-boiler could be converted in a similar way.

\section{System Study}

The study investigates the integration of a pyrolysis reactor and a combination with a gasifier, alternative with an electrolyser to produce $\mathrm{H}_{2}$, hydrogen, and also $\mathrm{O}_{2}$, oxygen, which can be used as complement to air in the combustion and gasification in a CFB boiler with the 
capacity of $150-180 \mathrm{MW}_{\text {th }}$ operating on biomass or organic waste. We then study complementing this with only a pyroliser or a combination with also a gasifier.

The sensitivity analysis includes the fluctuations in electricity price for purchased electric power, the price for biomass and waste as well as the annuity for the capital cost. Different operational modes are then evaluated assuming different demand of heat and electricity over a year in order to investigate reasonable operating hours for production of the liquid or gaseous fuel. Here also different products are assumed like pyrolysis liquid for HVO production (hydrogenated vegetable oil), methane and hydrogen. Hydrogen can be utilized either for refinement of the pyrolysis liquid directly or extracted and sold as a product for different applications like fuel to fuel cells or similar.

The system alternatives then become:

1. CFB with pyroliser (pyrolysis liquid as it is to a refinery).

2. CFB with gasifier (for hydrogen production primarily).

3. CFB with pyroliser combined with gasifier and gas upgrading with separation system.

4. CFB with pyroliser combined with electrolyser.

5. CFB with pyroliser combined with gasifier and gas upgrading with separation system plus electrolyser.

The system design with dimensioning of different equipment to balance the $180 \mathrm{MW}$ thermal capacity of the CFB boiler is carried out. Thereafter a rough cost estimate is made for the investment cost and maintenance cost for the different solutions. The annual costs for each system design is estimated. Concerning dual bed gasifiers Lundberg et al (2018) have presented conversion measured in a pilot plant and discussed scale up of this.

The assumptions for some different possible scenarios are based on heat demand for previous years. Year 2016 when the temperature dropped to $-20^{\circ} \mathrm{C}$ for several months, 2010 which was a harsh winter generally with much snow and 2019 when temperature has been quite high most of the time. On the other end we have summer 2018 when the temperature was $30^{\circ} \mathrm{C}$ and higher for two months. For "extreme periods" with very high or low temperature we look at hourly values, while normally monthly averages. From this we calculate energy demand with respect to heat, cooling and electricity and make a diagram showing the demand as a function of hours for each year.

We also look for the price of electricity, heat and cooling over the year for these years but also simulate other prices that might be expected in the future during different time periods. Here we look for how much of the total electricity production that comes from wind and solar power today and from this try to predict future probable price. When there is a lot of wind power we can expect low electricity price and then electrolyzes may be the best alternative for hydrogen production, and summertime solar power will be in surplus

The calculations are plotted in a diagram where we can compare cost of product as a function of hours per year, fuel cost and electricity cost. The products assumed are $\mathrm{H}_{2}$ and $\mathrm{HVO}$.

\section{Simulations}

The model is primarily energy and mass balances for the different equipment complemented with chemical reactions for combustion, gasification and pyrolysis as well as electrolysis.

$\frac{\partial m_{i}}{\partial t}=\left(\dot{m}_{\text {in }, i}-\dot{m}_{\text {out }, i}\right)$

$\frac{\partial m_{i}}{\partial t}=\mathrm{k}(\mathrm{T})^{*} m_{0, i}$

$\sum_{i}^{n} m_{i, \text { in }} x_{i, \text { in }}=\sum_{i}^{k} m_{i, o u t} x_{i, \text { out }}$

$\frac{\partial Q_{i}}{\partial t}=\left(\dot{m}_{i n, i}-\dot{m}_{o u t, i}\right) * C_{p, i} * \Delta T+\Delta \mathrm{H} * \frac{\partial m_{i}}{\partial t}$

Here $\dot{m}_{i n, i}$ is flow in (kg/s) of component $i$ and $\dot{m}_{\text {out }, i}$ is flow out. $\mathrm{k}(\mathrm{T})$ is a reactivity constant for a given reaction, $Q_{i}$ is the energy in $\mathrm{kWh}$ or kJ. $C_{p, i}$ is the heat capacity and $\Delta \mathrm{T}$ is the temperature difference. $\Delta \mathrm{H}$ is the heat released (or taken up) during the reaction.

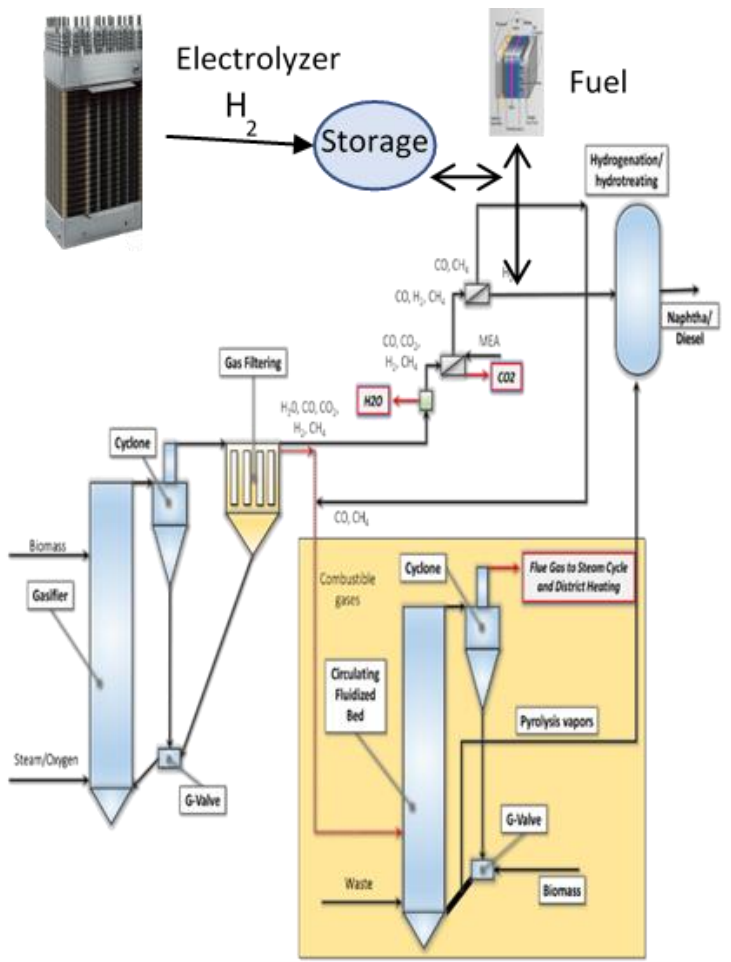

Figure 1. System with CFB boiler, pyrolyser, gasifier and electrolyser.

The fluidization of sand was determined from the balance between gas flow and buoyancy forces versus gravity forces. For full combustion this forms only $\mathrm{CO} 2$ 
and H2O. For the gasification we get different composition depending on the relative oxidation (how much $\mathrm{O} 2$ is added in comparison to what is needed for $100 \%$ combustion), capacity (ton $\mathrm{DS} / \mathrm{m}^{2} \mathrm{~h}$ ) and temperature. The gas composition for two different cases are given in Table 4 (Dahlquist et al, 2018). The energy balance in the CFB boiler is given in Table 1 and for the pyrolysis in the G-valve in Table 2 . The boiler considered is recycled wood CFB boiler at Malarenergi with approximately $150 \mathrm{MW}$ fuel feed. Part of this is used to heat sand which is passing over to the G-valve to heat fuel injected also there. This heat together with partial combustion is used as input to pyrolyse bio-mass and waste.

Table 1. Energy balance for the CFB boiler

\begin{tabular}{|l|c|}
\hline Alternative & 1 \\
\hline Fuel to CFB boiler & 7.7 \\
\hline $\mathrm{kgTS} / \mathrm{s}$ & 161.7 \\
\hline $\mathrm{MW} \mathrm{HHV}(21 \mathrm{MJ} / \mathrm{kg})$ & 146.3 \\
\hline $\mathrm{MW} \mathrm{LHV}(19 \mathrm{MJ} / \mathrm{kg})$ & \\
\hline Fuel to G-valve- pyrolyzer & 7.3 \\
\hline $\mathrm{kgTS} / \mathrm{s}$ & 152.5 \\
\hline $\mathrm{MW} \mathrm{HHV}$ & 138 \\
\hline $\mathrm{MW}$ LHV & \\
\hline Air boiler & 27.3 \\
\hline $\mathrm{m} 3 / \mathrm{s}$ & 35.3 \\
\hline $\mathrm{kg} / \mathrm{s}(1 \mathrm{~m} 3=1,293 \mathrm{~kg})$ & 29.3 \\
\hline $\mathrm{MW}$ to heat air to 850 oC & \\
\hline Air pyrolyzer & 3 \\
\hline $\mathrm{m} 3 / \mathrm{s}$ & 3.9 \\
\hline $\mathrm{kg} / \mathrm{s}$ & 1.7 \\
\hline $\mathrm{MW}$ to heat air to 450 oC & \\
\hline Sand to cyclone & 54.6 \\
\hline $\mathrm{kg} / \mathrm{s}$ & 850 \\
\hline temp boiler & 450 \\
\hline temp after pyro & 17.9 \\
\hline $\mathrm{MW}$ to pyrolyzer from sand & \\
\hline
\end{tabular}

Table 2. Energy balance for the pyrolyser.

\begin{tabular}{|l|c|}
\hline $\begin{array}{l}\text { Pyrolyzer } \\
\text { MW from combustion in pyrolyzer }\end{array}$ \\
\hline MW to heat fuel to 450 oC & 2.6 \\
\hline Losses & \\
\hline$\%$ & 11.5 \\
\hline $\mathrm{MW}$ (incl drive pyrolyzis) & 17.5 \\
\hline $\mathrm{MW}$ to drive pyrolyzis $1123 \mathrm{~kJ} / \mathrm{kg}$ & 8.2 \\
\hline Pyrolyzate liq & \\
\hline$\%$ & 64.6 \\
\hline $\mathrm{MW}$ & 98.5 \\
\hline $\mathrm{kg} / \mathrm{s}$ & 4.7 \\
\hline $\mathrm{kg} / \mathrm{h}$ & 16884 \\
\hline $\mathrm{Gas}$ from pyrolyzis & \\
\hline$\%$ & 7.1 \\
\hline $\mathrm{MW}$ & 10.8 \\
\hline Solid residue to CFB boiler from G-valve & \\
\hline$\%$ & 16.8 \\
\hline $\mathrm{MW}$ & 25.6 \\
\hline Sum MW from pyrolyzer to boiler & 36.4 \\
\hline
\end{tabular}

\subsection{Pyrolyser}

Pyrolysis demands $8.2 \mathrm{MW}$ while the heat from sand from the cyclone is $17.9 \mathrm{MW}$. Total losses are estimated to be $17.5 \mathrm{MW}$, assuming same proportion as in the small pilot plant. In reality losses can be reduced in a larger plant. Heat in gas and solids that are fed back to the CFB boiler are $36.4 \mathrm{MW}$ solid organic residues and 10.8 MW gaseous compounds. The heating value in the pyrolysis liquid is $98.5 \mathrm{MW}$ which correspond to 16.9 ton/h. Pyrolysis balances have been given in e.g. Neves et al (2015), where different conditions have been investigated. In our example we have used the balance presented by Atsonios et al. (2015) which is quite typical.

$1 \mathrm{~kg}$ bio-oil may contain $46.7 \mathrm{~mol} \mathrm{C}, 62 \mathrm{~mol} \mathrm{H}_{2}$ and 23.6 mol O. To remove $23.6 \mathrm{~mol} \mathrm{O}$ we then need $23.6 \mathrm{~mol}$ $\mathrm{H}_{2} .4 .69 \mathrm{~kg}$ liquid$/ \mathrm{s}$ means $23.6 \mathrm{~mol} \mathrm{O} / \mathrm{kg} * 4.69 \mathrm{~kg} / \mathrm{s}=$ $110.7 \mathrm{~mol} / \mathrm{s}$.

\subsection{Gasifier}

We have used experimental data from our pilot gasifier using wood pellets with 1.2 ton $\mathrm{DS} / \mathrm{m}^{2}, \mathrm{~h}$ at $42 \%$ relative oxidation (EOR) and steam addition. The gasification temperature was $670^{\circ} \mathrm{C}$. The gas composition was $8.4 \% \mathrm{H}_{2}, 10.9 \% \mathrm{CO}, 2.4 \% \mathrm{CH}_{4}, 17.8$ $\% \mathrm{CO}_{2}, 14.9 \% \mathrm{H}_{2} \mathrm{O}$ and $45.7 \% \mathrm{~N}_{2}$. In reality the water content is quite uncertain as an unknown amount was condensing in the sampling system. We have made two assumptions. In the first case we just have used air as oxidation media and not treated the gas before the membrane separation. In the second case we have used oxygen instead of air and first condensed out water to $90 \%$ and then removed $\mathrm{CO}_{2}$ to $90 \%$ using MEA. In the first case we can assume some $\mathrm{H}_{2} \mathrm{O}$ and some $\mathrm{CO}_{2}$ may be passed over with the $\mathrm{H}_{2}$ through the membrane, while 
in the second case the gas will be almost $100 \% \mathrm{H}_{2}$. In Table 3 we can see how the gas composition is changing over the different steps. In column 1 we have the raw gas after the gasifier. Then we have membrane filtrate where we have assumed $97 \%$ of the $\mathrm{H}_{2}$ as clean gas in column 2 and residual gas going back to the CFB boiler in column 3. In column 4 we have the "raw gas" after condensing out water to $90 \%$ and removed $\mathrm{CO}_{2}$ to $90 \%$ in a MEA scrubber or membrane filter with MEA at the back side. In column 5 we then have $100 \% \mathrm{H}_{2}$ and in column 6 the composition of the residual reject gas.

Table 3. The gas composition from raw gas to clean $\mathrm{H}_{2}$ respectively residual gas for the two alternatives - gas separation in membrane filter directly respectively after separation of $\mathrm{H}_{2} \mathrm{O}, \mathrm{CO}_{2}$ and not using air but oxygen from hydrolyzer.

\begin{tabular}{|c|c|c|c|c|c|c|c|}
\hline \multirow[b]{4}{*}{$\mathrm{H} 2 \%$} & \multirow{4}{*}{\begin{tabular}{|l|} 
Gas from \\
gasifier \\
8.4 \\
\end{tabular}} & \multirow{2}{*}{\multicolumn{2}{|c|}{\begin{tabular}{|l|} 
Membr separation \\
direct $97 \%$
\end{tabular}}} & \multicolumn{4}{|c|}{ No $\mathrm{N} 2$ and remove $\mathrm{H} 2 \mathrm{O}+\mathrm{CO} 2$ to $90 \%$} \\
\hline & & & & \multicolumn{4}{|c|}{ Feed gas Membr separaticRaw gas } \\
\hline & & Filtrate & Reject & \multicolumn{2}{|c|}{ to membr Filtrate } & \multicolumn{2}{|c|}{ Reject/without N } \\
\hline & & 100 & 0.27 & 33.5 & 100 & 1.5 & 20.5 \\
\hline $\mathrm{co \%}$ & 10.9 & & 11.8 & 43.6 & & 64.5 & 26.6 \\
\hline $\mathrm{CH} 4 \%$ & 2.4 & & 2.6 & 9.6 & & 14.3 & 5.9 \\
\hline $\mathrm{CO} \%$ & 17.8 & & 19.3 & 6.9 & & 10.3 & 43.4 \\
\hline $\mathrm{H} 2 \mathrm{O} \%$ & 14.9 & & 16.3 & 6.4 & & 9.4 & 3.7 \\
\hline $\mathrm{N} 2 \%$ & 45.6 & & 49.7 & 0 & 0 & 0 & 0 \\
\hline & 100 & & 100 & 100 & & 100 & 100 \\
\hline
\end{tabular}

Calculations are now made for two different cases. In the first case it is actual gas composition from our pilot gasifier where we operated at $670{ }^{\circ} \mathrm{C}, 42 \%$ relative oxidation and a capacity of 1.2 ton $\mathrm{DS} / \mathrm{m}^{2} . \mathrm{h}$. The moisture content was $30 \%$ by addition of steam to wood pellets (Table 4 case 1). The second case is using a regression model from many gasification experiments in the pilot plant and assuming $35 \%$ relative oxidation, 2 ton $\mathrm{DS} / \mathrm{m}^{2}$.h, $800{ }^{\circ} \mathrm{C}, 30 \%$ moist (Table 4 case 2 ).

Table 4. Gas composition and mol/kg DS for the different components for two different raw gas compositions.

\begin{tabular}{|l|c|c|c|c|c|}
\hline & Case 1 & \multicolumn{2}{l|}{ Case 2 } & & \\
\hline & \multicolumn{2}{|l|}{ Raw gas without N2 } & Raw gas & \multicolumn{2}{l|}{ Raw gas without N2 : } \\
\hline & water condensed out & \multicolumn{2}{l|}{ water condensed ou } \\
\hline & $\%$ & mol/kg DS & $\%$ & $\%$ & mol/kg DS \\
\hline $\mathrm{H} 2 \%$ & 20.5 & 17.7 & 20.2 & 40.7 & 41.6 \\
\hline $\mathrm{CO} \%$ & 26.6 & 14.9 & 12 & 24.2 & 18.2 \\
\hline $\mathrm{CH} 4 \%$ & 5.9 & 3.3 & 4.3 & 8.7 & 6.5 \\
\hline $\mathrm{CO} 2 \%$ & 43.3 & 24.4 & 11.8 & 23.8 & 17.8 \\
\hline $\mathrm{H} 2 \mathrm{O} \%$ & 3.7 & 6.4 & 13.6 & 2.7 & 2.8 \\
\hline $\mathrm{N} 2 \%$ & 0 & 0 & 38.1 & 0 & 0 \\
\hline tot & 100 & 66.7 & 100 & 100 & 86.9 \\
\hline $\mathrm{H} 2+\mathrm{CO}+\mathrm{CH} 4$ & & 39.2 & & & 72.8 \\
\hline
\end{tabular}

The balances for the pyrolyser is taken from Atsonios et al (2015). We have noticed that for $4.67 \mathrm{~kg}$ pyrolizate/s we need to remove $110.7 \mathrm{~mol} \mathrm{O} / \mathrm{s}$. For the first gas composition we produce $17.7 \mathrm{~mol} \mathrm{H}_{2} / \mathrm{kgDS}$. (110.7 mol $\left.\mathrm{H}_{2} / \mathrm{s}\right) /\left(17.7 \mathrm{~mol} \mathrm{H}_{2} / \mathrm{kgDS}\right)=6.25 \mathrm{~kg} \mathrm{DS} / \mathrm{s}$. If we can convert $\mathrm{CO}$ and $\mathrm{CH}_{4}$ to $\mathrm{H} 2$ as well we get $17.7+14.9+$ $2 * 3,3=39.2 \mathrm{~mol} \mathrm{H}_{2} / \mathrm{kg}$ DS. This would mean that 2.8 $\mathrm{kg} \mathrm{DS} / \mathrm{s}$ would be needed to the gasifier to cover the reduction of Oxygen in the pyrolisate. For the second gas composition (case 2) we get $41.6 \mathrm{~mol} \mathrm{H}_{2} / \mathrm{kg}$ DS which gives a demand of $110.7 / 41.6=2.7 \mathrm{~kg} \mathrm{DS} / \mathrm{s}$. If we convert also $\mathrm{CO}$ and $\mathrm{CH}_{4}$ to $\mathrm{H}_{2}$ through reaction with steam, we would get $72.8 \mathrm{~mol} \mathrm{H}_{2} / \mathrm{kg} \mathrm{DS}$ and a demand of $110.7 / 72.8=1.52 \mathrm{~kg} \mathrm{DS} / \mathrm{s}$. From this we can see that how the system is designed and how the gasifier is operated will have a significant effect on the capacity of the gasifier. With the second case the size would be 43 $\%$ compared to the first case for only $\mathrm{H}_{2}$ utilized and 54 $\%$ if also $\mathrm{CO}$ and $\mathrm{CH}_{4}$ is converted to $\mathrm{H}_{2}$.

If we have a HHV of the fuel at $21 \mathrm{MJ} / \mathrm{kg}$ we would need a gasifier with $1.52 * 21=31.9 \mathrm{MW}$ while in the case 6.25 $\mathrm{kg} \mathrm{DS} / \mathrm{s} * 21 \mathrm{MJ} / \mathrm{kg}$ the capacity would be $131 \mathrm{MW}$. Cost estimates for the gasification and enrichment of $\mathrm{H}_{2}$ has been presented in Naqvi et al (2017). We use the figure $70 \mathrm{M} €$ for a $180 \mathrm{MW}$ gasifier plant and use the scaling factor 0.8 , which gives $23.5 \mathrm{M} €$ for case 1 and 17.6 M€ for case 2 . If we look at alternative 5 where we combine gasifier with electrolyser we get 13.5 respectively 10.1 $\mathrm{M} €$ for the gasifiers but have to add the cost for electrolyser as well.

\subsection{Electrolyser}

Electrolysers use electricity to split water into $\mathrm{H}_{2}$ and $\mathrm{O}_{2}$. If we have a demand of $110.7 \mathrm{~mol} \mathrm{H} / \mathrm{s}$ it means that we also produce $55.4 \mathrm{~mol} \mathrm{O}_{2}(110.7 \mathrm{~mol} \mathrm{O})$. This can be used in the combustion, but especially in the pyrolyser and the gasifier if we combine with also this.

For the electrolyser we can assume the price to be some $500 € / \mathrm{kW}$ at large scale up to the double for small scale electrolysers. Typically, one $\mathrm{kg} \mathrm{\textrm {H } _ { 2 }}$ demand $58 \mathrm{kWhel}$ for production, which means $0.017 \mathrm{~kg} \mathrm{H}_{2} / \mathrm{h}$ with one $\mathrm{kW}$ input electricity. For the demand $0.22 \mathrm{~kg} \mathrm{H}_{2} / \mathrm{s}$ then means a capacity of $0.221 \mathrm{~kg} \mathrm{H}_{2} / \mathrm{s} /\left(0.0000047 \mathrm{~kg} \mathrm{H}_{2} / \mathrm{s}\right)=$ $46800 \mathrm{~kW}$. For alternative 5 a $23400 \mathrm{~kW}$ electrolyser is needed. We assume 0.12 as annuity $(4 \%, 10 \mathrm{y})$ and cost for electricity in the range $1-10 € c e n t / \mathrm{kWh}_{\mathrm{el}}$. The prize of electricity will be dominating. When there is a surplus of electricity production we will be in the lower range of the span, while when there is a deficiency the prize will be in the upper range. This makes it more complicated to decide best technology. It would be good to have both gasifier and electrolyser and use the biogasifier when electricity prize is high, and electrolyser when it is low. If we assume a cost of $500 \$ / \mathrm{kW}$ it means $446 € / \mathrm{kW}$ in investment cost. This would give an investment cost of $20.9 \mathrm{M} €$ for the $46800 \mathrm{~kW}$ unit and $10.5 \mathrm{M} €$ for the $23400 \mathrm{~kW}$ unit.

\section{Results and discussion}

In Tables 5-7 we see the capacities for the different alternatives. We have assumed a biomass fuel price of $14 € / \mathrm{MWh}$, which is average today. For electricity we have assumed $10 € / \mathrm{MWh}$ and $35 € / \mathrm{MWh}$, as we expect quite strong variation over the year, depending on the 
balance between production and consumption. We also have looked at 5000 hours and 7000 hours of operations per year. All equipment is assumed having 20 years life time and 5\% interest rate, giving annuity 0.081 . Concerning the gasification and electrolyzes the figures are reasonable, while for the pyrolysis it is more of a "guestimate". The cost figures are taken from Naqvi et al (2017). There already are vessels for pyrolysis at the CFB boilers, the G-valves, but addition is needed with fuel feeder, gas outtake and gas condensation. As the reactor for $\mathrm{H}_{2}$ with pyrolysis liquid is principally same for all alternatives except for alternative 1, it has not been included. We have assumed the value of the pyrolysis liquid to be $70 \%$ of the refined (reacted with $\mathrm{H}_{2}$ ) for case 1. For case 2 we have just assumed same value for $\mathrm{H}_{2}$ as for pyrolysis liquid. For case 2 and 3 we have added a cost for membrane separation for $\mathrm{H}_{2}$ enrichment of $10 \mathrm{M} €$, and for case 5 half of this. These figures are taken from Naqvi et al (2017).

Table 5. 5000 hours per year, biofuel cost $14 € / \mathrm{MWh}$, electricity $10 € / \mathrm{MWh}$, annuity 0.081 .

\begin{tabular}{|l|c|c|c|c|c|}
\hline $5000 \mathrm{~h} /$ year & Case & & & & \\
\hline Total cost incl capital/y & 1 & 2 & 3 & 4 & 5 \\
\hline Capital cost(0.081) M€ & 3.2 & 2.7 & 6 & 4.9 & 5.5 \\
\hline Fuel 5000 h/y 14 €/MWh & 13.9 & 12.3 & 19.4 & 17.2 & 12.3 \\
\hline Cost el 10€/MWh & & & & 2.3 & 1.2 \\
\hline Total cost per year & 17.1 & 15 & 25.4 & 24.4 & 18.9 \\
\hline Income pyroliq & 17.2 & 24.6 & 24.6 & 24.6 & 24.6 \\
\hline Gross benefit & 0.12 & 9.7 & -0.7 & 0.2 & 5.7 \\
\hline
\end{tabular}

Table 6. 7000 hours per year, biofuel cost $14 € / \mathrm{MWh}$, electricity $10 € / \mathrm{MWh}$, annuity 0.081 .

\begin{tabular}{|l|c|c|c|c|c|}
\hline $7000 \mathrm{~h} / \mathrm{y}$ el $10 € / \mathrm{MWh}$ & Case & & & & \\
\hline Total cost incl capital/y & 1 & 2 & 3 & 4 & 5 \\
\hline Capital cost(0.081) M€ & 3.2 & 2.7 & 6 & 4.9 & 5.5 \\
\hline Fuel 7000 h/y 14 €/MWh & 19.4 & 19.4 & 19.4 & 19.4 & 17.2 \\
\hline Cost el 10€/MWh & & & & 3.3 & 1.6 \\
\hline Total cost per year & 22.6 & 22.1 & 25.4 & 27.6 & 24.3 \\
\hline Income pyroliq & 24.1 & 34.5 & 34.5 & 34.5 & 34.5 \\
\hline Gross benefit & 1.5 & 12.4 & 9.1 & 6.9 & 10.2 \\
\hline
\end{tabular}

Table 7. 7000 hours per year, biofuel cost $14 € / \mathrm{MWh}$, electricity $35 € / \mathrm{MWh}$, annuity 0.081

\begin{tabular}{|l|c|c|c|c|c|}
\hline $7000 \mathrm{~h} / \mathrm{y}$, el $35 € / \mathrm{MWh}$ & Case & & & & \\
\hline Total cost incl capital/y & 1 & 2 & 3 & 4 & 5 \\
\hline Capital cost(0.081) M€ & 3.2 & 2.7 & 6 & 4.9 & 5.5 \\
\hline Fuel 7000 h/y 14 $€ / \mathrm{MWh}$ & 19.4 & 19.4 & 19.4 & 19.4 & 17.2 \\
\hline Cost el 35€/MWh & & & & 11.6 & 5.8 \\
\hline Total cost per year & 22.6 & 22.1 & 25.4 & 35.9 & 28.4 \\
\hline Income pyroliq & 24.1 & 34.5 & 34.5 & 34.5 & 34.5 \\
\hline Gross benefit & 1.5 & 12.4 & 9.1 & -1.4 & 6.1 \\
\hline
\end{tabular}

Table 8. 7000 hours per year, biofuel cost $14 € / \mathrm{MWh}$, electricity $100 € / \mathrm{MWh}$, annuity 0.081

\begin{tabular}{|l|c|c|c|c|c|}
\hline $7000 \mathrm{~h} / \mathrm{y}$, el $100 € / \mathrm{MWh}$ & Case & & & & \\
\hline Total cost incl capital/y & 1 & 2 & 3 & 4 & 5 \\
\hline Capital cost(0.081) M€ & 3.2 & 2.7 & 6 & 4.9 & 5.5 \\
\hline Fuel 7000 h/y 14 €/MWh & 19.4 & 19.4 & 19.4 & 19.4 & 17.2 \\
\hline Cost el 35€/MWh & & & & 33 & 16.5 \\
\hline Total cost per year & 22.6 & 22.1 & 25.4 & 57.3 & 39.1 \\
\hline Income pyroliq & 24.1 & 34.5 & 34.5 & 34.5 & 34.5 \\
\hline Gross benefit & 1.5 & 12.4 & 9.1 & -22.9 & -4.7 \\
\hline
\end{tabular}

From the results we can see that for 5000 hours operations the alternative with a smaller gasifier and a smaller electrolyser looks like a good alternative. The electrolyser is then used to produce both $\mathrm{H}_{2}$ and $\mathrm{O}_{2}$. The $\mathrm{O}_{2}$ is used in the gasifier, and thereby giving a better gas from the gasifier, without $\mathrm{N}_{2}$ from the air. For 7000 hours most cases are economic at low electricity price, but especially alternative 4 becomes very unprofitable with the higher electricity price. As we don't have very accurate figures for the value of pyrolysis liquid of different qualities, and neither for large amounts of $\mathrm{H}_{2}$, the results are more giving relative impact of different alternatives, but clearly show the importance of cost for both biomass and electricity. If we could use waste instead of biomass, we would have an income of 12 $€ / \mathrm{MWh}$ instead of a cost for the better biomass of 14 $€ / \mathrm{MWh}$, but instead there would be an issue of what quality the pyrolysis liquid would have, if there is e.g. halogens from PVC in the plastic fraction.

From the analysis we can see that the span with respect to economy is high for the different alternatives. This is due to high difference in prize for different fuels both right now, but certainly also in the future. The capital cost also has gone down a lot last years for electrolysers and probably will proceed going down if the technology will be used much more frequently than in the past. We also can see that the sizing of especially the gasification plant will depend a lot on how much oxygen there will be in the liquid product after the pyrolysis. From literature we can see that the amount of oxygen varies between some 20 to $50 \mathrm{wt}$. \%. If we can utilize both $\mathrm{H}_{2}$ and $\mathrm{CO}$ for reduction of $\mathrm{O}$ in the liquid product it will also make a large difference compared to if only $\mathrm{H}_{2}$ is used. Still, we have reliable figures on many process parts verified in both own experiments on gasification of different biomass and black liquors as well as reports from literature from experiment in pilot and demonstration plants, showing that each part of the processes are possible to get to work, although the complete systems have not been implemented yet.

\section{Conclusions}

The study shows that different system solutions can be the most economic depending on the conditions. If the price for pyrolysis liquid is good even without hydrogenating it, case 1 may be interesting. If there is a strong demand for $\mathrm{H}_{2}$ as such, case 2 is feasible. If the value of the pyrolysis liquid is much higher after hydrogenation the addition of the gasifier make sense as in case 3. If the electricity price is low case 4 is good. If the electricity price is varying case 5 make sense, and also it is positive that the $\mathrm{O}_{2}$ produced in the electrolyser can be utilized in the gasification. Thereby we get a $\mathrm{N}_{2}$ free gas which is much easier to handle than gas with high amount of $\mathrm{N}_{2}$. The cost figures are of varying quality and thus next step will be to do more detailed cost estimates and more detailed design. Here we will 
utilize the simulation model we have developed to give the possibility to do more sensitivity analysis.

\section{Acknowledgements}

We are most thankful for the financial contribution made by EU Horizon 2020- SPIRE-2 for the project FUDIPO. The content of the paper will also be included in a technical report produced by the project. We also thank Joacim Sundqvist at Mälarenergi AB for input.

\section{References}

S. Ahmeddin and H. Mohamed. Techno-economic evaluation for pyrolysis and gasification process integration with $\mathrm{CHP}$ plants to produce biofuels (Master's thesis), 2020. http://urn.kb.se/resolve?urn=urn:nbn:se:mdh:diva-49014.

K. Atsonios, K. Panopoulos and E. Kakaras. Biomass fast pyrolysis energy balance of a $1 \mathrm{~kg} / \mathrm{h}$ test rig. International Journal of Thermodynamics, 267, 2015. doi: 10.5541/ijot.5000147483.

E. Dahlquist, M. Naqvi, E. Thorin, J. Yan, K. Kyprianidis and Philip Hartwell. Modeling of Wood Gasification in an Atmospheric CFB Plant. In Proceedings of SIMS 2018, September 26 - 27, 2018, Oslo, 872-877, 2018. doi:10.3384/ecp17142872.

Fortum Corporation. Bio-oil plant in Juensuu, 2013. https://www.fortum.com/media/2013/11/fortums-bio-oilplant-commissioned-joensuu-first-its-kind-world.

E. Jonsson. Slow Pyrolysis in Brista: An Evaluation of Heat and Biochar Production in Sweden (Dissertation), 2016. http://urn.kb.se/resolve?urn=urn:nbn:se:kth:diva-188601.

A. Larsson, M. Seemann, D.Neves and H. Thunman. Evaluation of Performance of Industrial-Scale Dual Fluidized Bed Gasifiers Using the Chalmers 2-4-MWth Gasifier. Energy Fuels, 27:6665-6680, 2013. doi: 10.1021/ef400981j.

A. Larsson, I. Gunnarsson and F. Tengberg. The GoBiGas Project Demonstration of the production of Biomethane from Biomass via Gasification. Göteborg Energi, 2018. 10.13140/RG.2.2.27352.55043.

L. Lundberg, D. Pallarès and H. Thunman. Upscaling Effects on Char Conversion in Dual Fluidized Bed Gasification. Energy Fuels, 32, $2018 . \quad$ doi: 10.1021/acs.energyfuels.8b00088.

M. Naqvi, E. Dahlquist and J. Yan. Complementing existing CHP plants using biomass for production of hydrogen and burning the residual gas in a CHP boiler. Biofuels, 8:1-9, 2016. doi:10.1080/17597269.2016.1153362.

D. Neves, H. Thunman, A. Matos, L. Tarelho and A. GómezBarea. Characterization and prediction of biomass pyrolysis products. Fuel and Energy Abstracts. 37:611-630, 2011. doi:10.1016/j.pecs.2011.01.001.

R. Rauch, H. Hofbauer, K. Bosch, I. Siefert, C. Aichernig, H. Tremmel, K. Voigtlaender, R. Koch and R. Lehner. Steam gasification of biomass at CHP plant in Güssing - status of the demonstration plant. In Proceedings-2nd World Conference and Technology Exhibition on Biomass for Energy, Industry and Climate Protection. 1687-1690. 2004.

Setra group. Setra och Preem först i Europa med förnybara drivmedel från sågspån. https://www.setragroup.com/sv/press/pressmeddelanden/2 019/setra-och-preem-forst-i-europa-med-fornybaradrivmedel-fran-sagspan/. 2019. 